\title{
Трансформации социальной политики и дискурса социальной справедливости в России
}

\author{
Е.Н. ДАНИЛОВА*
}

\begin{abstract}
*Елена Николаевна Данилова - кандидат социологических наук, руководитель, Центр теоретических и историко-социологических исследований, Институт социологии РАН; Федеральный научно-исследовательский социологический центр РАН. Адрес: 117218, Москва, ул. Кржижановского 24/35, к. 5. E-mail: endanilova@gmail.com

Цитирование: Данилова Е.Н. (2018) Трансформации социальной политики и дискурса социальной справедливости в России // Мир России. Т. 27. № 2. С. 36-61. DOI: $10.17323 / 1811-038 X-2018-27-2-36-61$
\end{abstract}

В статье рассмотрень изменения сочиальной политики в сочетании с трансформациями дискурса о социальной справедливости. Выделяются несколько этапов: советское время, перестройка и период реформ в постсоветской России. Анализируются основные акиенты и обсуждаемые вопросы, которые стояли на повестке дня сочиальной политики в каждый из периодов, а также дискурс о социиальной справедливости в официальной риторике, экспертных мнениях (прежде всего относительно социального неравенства) и режимах соииального государства. Споры о сочиальной справедливости встроены в идеологический дискурс и усиливаются в преддверии и сопровождении масштабных соцчиальных изменений. В статье показано, что российская социальная политика, будучи отражением внутриполитической борьбы под воздействием экзогенных и эндогенных факторов на каждом из перечисленных этапов, трансформировалась в модель, не похожую ни на одну из существуюших. Она имеет гибридный характер: последовательная ориентация на неолиберальную логику реформ сочетается с авторитарно-бюрократической машиной управления и специфическим набором техник государственного распределения и регулирования. Сочиальная политика даже в годы относительного подъема практически не меняла ситуацию социального неравенства, установивщуюся в начале 1990-х годов.

Ключевые слова: социальная справедливость, дискурс, социальная политика, реформы, социальное государство, социальное неравенство 


\section{Введение}

В статье предпринята попытка анализа развития дискурса социальной справедливости и социальной политики России с конца XX в. - времен СССР, перестройки и реформ в постсоветской России. В разные периоды цели и приоритеты социальной политики менялись, и немалую роль в формулировании направлений ее развития играли представления о социальной справедливости. Считается, что эта ценность традиционна для российского общества. В течение многих веков она выступала ядром всего нравственного мира в нашей стране [Концепция 1994]. В то же время актуализация идеи справедливости не уникальна для России: она характерна для нравственной оценки социального устройства любого общества. Классическая социология со времен Э. Дюркгейма признает, что прочной основой социального порядка являются моральные и нравственные чувства людей, связанные с их представлениями о справедливом обществе. Социальная справедливость - это весьма тонкий предмет, вызывающий немало теоретических и морально-нравственных споров.

В данной статье рассматривается дискурс социальной справедливости как часть идеологического проекта и нормативной основы для формирования консенсуса в обществе. Споры о содержании социальной справедливости артикулируются и интенсифицируются в преддверии и сопровождении масштабных социальных трансформаций в качестве фрагмента идеологического проекта, как правило, продвигаемого элитами в зависимости от того, какие политические и экономические вопросы стоят на повестке дня. Обращение к социальной справедливости позволяет им легитимировать существующие меры или предстоящие изменения в социальной политике.

С другой стороны, общественный запрос на социальную справедливость по большей части выражается в чувствах ресентимента, что в свою очередь опосредовано текущим положением людей и их оценками своего собственного положения и возможностями улучшения жизни. И если правила игры в обществе ощутимо отклоняются от представляемого справедливого общественного устройства, то имеются основания для требований перемен, а политики со своей стороны апеллируют к переживаемым чувствам и ресентиментам.

Концепция социальной справедливости, формулируемая в официальном, научном и публичном дискурсах, менялась. Ко времени начала российских реформ была создана почва для нового содержания социальной справедливости. И в последнее время мы наблюдаем активизацию дискуссий о социальной справедливости. Является ли это запросом на изменения?

Другим теоретически важным конструктом и предметом дискуссий выступает понятие социального государства, поскольку социальная справедливость встроена в него весьма прочно. Социальное государство добивается приемлемых условий жизнедеятельности во всех слоях общества на основе расширения своих социальных функций с целью обеспечения социальной справедливости благодаря разумному сочетанию частных интересов и интересов общества и недопущения значительного социального расслоения. Согласно Конституции 1993 г., Россия социальное государство, но что понимается под данной формулировкой? Насколько дистрибутивные механизмы и проблема социального неравенства являются важным аспектом модели социальной политики и споров о справедливости? 
Изменения в российской социальной политике на протяжении десятилетий после распада СССР привели к замене модели, «к тому, что сейчас мы имеем дело и с другим государством, другой социальной политикой, другими институтами, ее обеспечивающими» [Романов 2003].

\section{Периоды трансформаций}

\section{Советский период}

По поводу той модели социального политики, которая существовала в советские годы, имеются противоречивые точки зрения. С одной стороны, заявляют о ее явных преимуществах, среди которых развитая система социального обеспечения, с другой, критикуют за сдерживание экономического развития, уравнительную систему и укоренение патерналистских, иждивенческих и эгалитарных установок [George, Manning 1980; Концепция 1994; Романов 2003; Сидорина 2005; Григорьева 2008 и др.]. Во времена СССР эгалитарные распределительные отношения признавались главенствующими, и гарантом соответствующей социальной политики выступало государство. Показательна цитата того времени: «Представления о социальной справедливости - это совокупность норм, убеждений, теорий о том, как должны распределяться в обществе жизненные блага» [Лойко 1985, с. 99].

Интересно, что сам термин «социальная справедливость» в официальном и научном дискурсе в начале советского периода практически не использовался и появился с заметным опозданием. В 1930-1950 гг. также существовало негласное табу на исследования проблем социальной справедливости ${ }^{1}$. Возникнув сначала как морально-правовая категория, понятие «справедливость» постепенно приобрело общественно-политическое значение, стало мерилом для оценки качества социального порядка [Епихина 2016, с. 131].

В СССР существовало базовое официальное представление о социальной справедливости, которое формулировалось исходя из марксистских идей о модели бесклассового общества, и упор делался на ликвидацию классовых неравенств и должном распределении благ. Сложность вызывало последнее: при социализме представления о социальной справедливости основывались на изначальном равенстве всех членов общества по отношению к средствам производства, а также равном праве на социальные блага (труд, здоровье, образование и т.д.), а конечной целью общественного развития провозглашались преодоление отчуждения и максимальная личностная реализация каждого члена общества. Формула социальной справедливости базировалась на основном принципе социализма «от каждого по способностям, каждому - по труду», при этом правило «каждому - по труду» вынуждало учитывать различия трудового вклада в приращение общественного богатства, подлежащего распределению.

При советской власти социальная политика основывалась на распределительных отношениях, а ее цели управлялись эгалитарной идеологией, даже если на

1 В Большой советской энциклопедии термин «справедливость» появился только в 1953 г. 
практике их было трудно реализовать из-за отсутствия необходимых ресурсов. При господстве этой идеологии приоритеты в рассмотрении социальной справедливости менялись в зависимости от экономической повестки с учетом социального контекста и практических задач, связанных с регулированием трудовых отношений и повышением производительности труда.

Трансформация социальной политики, тесно взаимодействовавшей с экономикой, происходила постоянно, при этом баланс их взаимодействия также менялся. Если коротко говорить об этапах развития, то многие исследователи связывают социальную политику времен Советского Союза с экономическими задачами. Так, П.В. Романов выделяет несколько периодов: в течение первого десятилетия существования СССР формы социальной политики были тесно связаны в основном с политикой стимулирования трудовой деятельности, становления трудовой дисциплины и поощрения роста производительности труда; до начала 1950-х гг. социальная политика была нацелена прежде всего на развитие трудовых ресурсов для ускоренной индустриализации; и только с конца 1950-х гг. она находилась в более сбалансированных отношениях с экономикой [Романов 2003]. В ее приоритеты входило удовлетворение социальных потребностей населения, означавшее увеличение государственных расходов и внимание к производству товаров народного потребления, предоставлению бесплатных или почти бесплатных социальных и бытовых услуг населению [George, Manning 1980; Manning, Shkaratan, Tikhonova 2000]. В рамках широкомасштабных хрущевских реформ (1956-1964 гг.) снижение социального неравенства стало приоритетным: законодательство 1956 и 1964 гг. модернизировало систему социального обеспечения и сделало ее одной из лучших в мире в отношении равенства доступа и объема услуг. Реформы 1958-1959 гг., затронувшие сферу образования ${ }^{2}$, были направлены на выравнивание шансов его получения [Гусев, Калашников, Качанов, Колобашкин и др. 1982]. К 1980-м гг. была выстроена одна из самых эффективных в мире систем здравоохранения, в частности, по универсальности и доступности, количеству врачей на тысячу человек населения [Романов 2003]. Однако, несмотря на все достижения социальной политики, уровень жизни советских людей был крайне низок, в первую очередь, ввиду низких зарплат и недостатка жилья, и, несмотря на значительные инвестиции в жилищную сферу в течение всего советского периода, проблема обеспечения людей нормальным жильем оставалась весьма далекой от своего решения.

С течением времени советский дискурс о социальной справедливости все больше сталкивался с серьезным противоречием: с одной стороны, с обязательностью признания изначального равного права всех на социально значимые блага, с другой, с необходимостью учета существующих неравенств. Противоречие со временем нарастало и при оценке проводимой социальной политики начинало проявляться более отчетливо.

В годы позднего социализма коннотация социальной справедливости изменилась, в большей степени приобретая экономическое наполнение и именно в этом аспекте выступая в качестве интегративной оценки общественных отношений. «Требования справедливости неразрывно связаны с экономической необходимостью и целесообразностью, и тем самым выявляют взаимосвязь экономических и нравственно-оценочных отношений» [Кузнецьов 1984, с. 149]. Более того,

2 Например, в 1958 г. восьмилетнее среднее образование стало обязательным для всех. 
на повестку дня также вышли несовершенные механизмы распределения в сфере регулирования трудовых отношений и эффективности производства. При этом недоработка трудового законодательства, начисления заработной платы и премий по формальным признакам, уравниловка в оплате труда рассматривались как отклонения от принципов справедливости.

Уже с середины 1980-х гг. понятие «социальная справедливость» начинает рассматриваться не только как морально-правовая или социально-политическая категория, но и как действенный критерий оценки эффективности экономической системы. Если экономика плохо работает, одна из причин этого заключается в неправильной работе механизмов распределения, а значит, в недостатке социальной справедливости [Мальцеев 1985]. При этом эгалитарные представления и роль государства сомнению не подвергались. Равенство и унификация в получении социальных благ составляли базу существующей системы распределения, которая подверглась критике позже.

По мнению Е.Ш. Гонтмахера, «в советское время государство практически полностью контролировало уровень жизни населения. Для этого использовались мощнейшие перераспределительные механизмы: общественные фонды потребления и централизованная бюджетная система. Регулирование заработной платы путем тарифной сетки, бесплатное образование и здравоохранение, доступность учреждений культуры, отдыха выгодно отличали СССР от других стран мира» [Гонтмахер 2007, с. 1]. Автор также признает, что социальная политика не давала возможности возникнуть серьезному социальному неравенству, а социальное устройство было внутренне сбалансировано и стабильно.

Однако негативные тенденции накапливались, и противоречия, встроенные в понимание справедливости, равенства и неравенства, обострялись. Суть институтов благосостояния при социализме укладывается в формулировку Дж. Оруэлла «все ... равны, но некоторые равнее».

\section{Перестройка}

Особенностью периода перестройки является активное концептуальное переформулирование идеологических принциипов социчальной справедливости и социальной политики. В это время темпы политических преобразований опережали показатели экономических трансформаций, и поэтому особенно острыми были дебаты о социальной справедливости, под лозунгом которой проводилась перестройка. В эти годы образовалось и новое дискуссионное идеологическое поле, появилось большое количество текстов, формулирующих принцип социальной справедливости. «После XXVII съезда КПСС начинается новая страница в истории понятия справедливости. Оно покидает узкие рамки общественных наук и становится частью общественного дискурса. На страницах печати - как профессиональных, так и популярных периодических изданий - разворачиваются острые дискуссии, предметом которых становятся факты, планы реформирования, так или иначе затрагивающие проблему справедливости» [Епихина 2016, с. 137].

В профессиональной среде основной дискуссионной площадкой стал журнал «Коммунист», где была опубликована статья академика Т.И. Заславской «Челове- 
ческий фактор развития экономики и социальная справедливость», послужившая поводом для начала широкого диспута [Заславская 1986]. В этой статье, в частности, обосновывалась необходимость дифференцированного подхода к реализации социальной политики и подчеркивалось, что советское общество состоит из элементов, демонстрирующих разную степень социальной и экономической эффективности и отдачи, соответственно, потребности всех элементов общества не могут удовлетворяться государством в одинаковой степени, и посему от прежнего советского принципа социальной справедливости, согласно которому все члены общества имеют равный доступ к социальным благам, необходимо перейти к социальной политике, дифференцированной на основании разной сочиальной и экономической эффективности членов общества.

Другой знаковой публикацией можно назвать статью П.О. Авена «Механизм распределения и социальная справедливость» [Авен 1987], где автор подчеркивал связь представлений о социальной справедливости с экономическими интересами членов общества: «Представления о социальной справедливости - важнейший индикатор экономических интересов, и от того, как члены общества понимают социальную справедливость, какими видят пути ее обеспечения, во многом будет зависеть успех» [Авен 1987, с. 115]. П.О. Авен перенес акцент на экономическую и индивидуалистическую составляющую понятия «социальная справедливость» и поднял вопрос о необходимости введения платных услуг в тех сферах общественной жизни, в которых с наибольшей остротой проявились противоречия между требованиями социальной справедливости и экономической эффективностью социальной сферы: в медицине, обеспечении жильем, образовании.

Исследователи того времени отмечали, что «монетарные отношения вытеснялись идеологическими, а все попытки расширить личную экономическую свободу расценивались как политически нелояльное, близкое к криминальному поведение» [Осипенко 1986; Шохин 1987, с. 85].

В качестве другой дискуссионной линии в тот период следует упомянуть аргументы социально-ориентированных противников уравнительного принципа, которые исходили из соображений общего блага. Чувство справедливости рассматривалось ими как социальный продукт, продукт социализации и формировалось в зависимости от позиции субъекта в системе распределения. Различалось два типа справедливости. Справедливости «для всех» противопоставлялась индивидуалистическая справедливость (коллективистское понимание справедливости, исходящее из эгалитарной идеологии и выражающееся как забота об общем благополучии); Коллективистское понимание социальной справедливости свойственно «людям труда», т.е. тем, кто непосредственно вносит свой вклад в систему общественного производства и распределения социально значимых благ (бесплатное образование, медицинское обслуживание и т.д.), поэтому и улучшение жизни должно происходить путем совершенствования социального обеспечения. Другой тип - справедливость индивидуалистическая, воплощается в заботе о личном благополучии, в «заботе отдельного человека по поводу того, что живет ли он хуже или лучше других» [Наумова, Роговин 1987, с. 13]. Здесь проблемой было то, что носители индивидуалистических представлений о социальной справедливости (представители социальных групп, обладающих собственными материальными благами, количество которых сделало возможным получение значимых социальных благ «сверх положенного») выступали «<..> против попыток общества создавать 
всем достойные человека условия существования, т.е. компенсировать неоправданные, незаслуженные лишения с помощью политики перераспределения, будь то использование фондов общественного потребления или введение прогрессивного налога на наследство» [Наумова, Роговин 1987, с. 13] $]^{3}$. В этой связи следует упомянуть дискуссию о нетрудовых доходах, получаемых, например, представителями номенклатуры благодаря их привилегированному положению. Решение проблемы виделось в совершенствовании законодательной базы (например, введение прогрессивного налога) и регулировании распределительных отношений.

В период перестройки преобладала точка зрения, что уравнительный принцип в распределении социальных благ является источником социальной несправедливости и социальной напряженности. На фоне трансформаций, произошедших в конце 1980-х гг. (введение хозрасчета, платных услуг, индивидуальной и кооперативной организации труда) и начале 1990-х (экономический кризис, острый дефицит товаров при тяжелом внутреннем и внешнеполитическом контексте), произошла и смена парадигмы социальной справедливости с акцентом на индивидуалистическую и экономическую составляюшую. По сути, во времена перестройки была подготовлена идеологическая платформа для новой концепции социальной справедливости и социальной политики, которая начала реализовываться позже, в 1990-х гг.

Поиск коридора возможностей в области социальной политики для выработки компромисса между требованиями эффективности и запросами на справедливость отчетливо проявлялся в дискуссиях в эпоху позднего СССР и до сегоднящнего дня.

\section{Постсоветское время}

После распада СССР началось кардинальное реформирование социальной сферы: именно в 1990-е гг. была разработана основа перехода к новой модели социальной политики, обусловленной рыночной экономикой. В 1993 г. в Конституции России появился термин «социальное государство», заимствованный из концепции рыночной экономики welfare state. В тот период исследователи часто обращались к режимам социального государства, описанным в западной литературе. Особое место здесь занимает признанная классической работа Г. Эспинг-Андерсена [Esping-Andersen 1990], по мнению которого, предложенная классификация особенно полезна для идентификации векторов развития, особенно в тех странах, где институты благосостояния формируются столь противоречиво, как в России [Якобсон 2010].

В настоящее время можно найти разные вариации классификаций [Сигов, Слуцкий 2006; Ярская 2003; Церкасевич 2002 и др.], но все они в определенной мере перекликаются с классификацией Г. Эспринг-Андерсена, выделявшего три режима государства благосостояния (social welfare):

(1) либеральный режим (или англо-саксонский) направляет социальные программы на самых бедных, остальные группы населения пользуются преимуществами рынка;

3 Различия двух типов справедливости особенно отчетливо проявились в вопросе о наследстве [Роговин 1985]. 
(2) консервативно-корпоративный (или христианско-демократический) основан на принципе субсидиарности, когда социальные проблемы должны решаться на местном или удаленном от центра уровне, при этом центральная власть играет «субсидиарную» (вспомогательную, а не «субординативную», подчиняющую) роль; в этой ситуации сам режим сохраняет статусные различия социальных групп;

(3) самой прогрессивной формой Г. Эспинг-Андерсен и его единомышленники признавали социал-демократический режим в скандинавских странах, где гарантируется как универсализм социальных прав, так и нерушимость индивидуальной автономии при сильной роли государства, а государство со своей стороны участвует в финансировании, например, обеспечения бесплатного образования и бесплатной страховой медицины.

Напомним, что, когда Г. Эспинг-Андерсен писал ставшую классической книгу, в мире уже происходили серьезные трансформации, и автор, обеспокоенный проблемами неравенства, анализировал модели в зависимости от того, в какой степени они способствуют или противодействуют влиянию рынка. Ключевое понятие в подходе Г. Эспинг-Андерсена - декоммодификащия, обозначающее ослабление зависимости индивидуального и группового благосостояния от действия рыночных сил.

В западных рыночных экономиках кризис модели социального государства (welfare state), сформулированной еще в середине XX в., пришелся на конец 1970-х - начало 1980-х гг. Во второй половине XX в. большинство развитых стран столкнулись с финансовыми проблемами, связанными с последствиями глобализации, - деиндустриализацией и ослаблением налоговой базы. Неолиберальные критики, отстаивавшие невмешательство государства в рыночную экономику и утверждавшие, что государство всеобщего благосостояния приводит к «социальному иждивенчеству» и падению эффективности экономики, определили дальнейшую судьбу социальной политики. Под воздействием неолиберальной идеологии произошла постепенная смена парадигмы - отход от социального государства (retrenchment), характер которого радикально изменился. Уже в течение 1980-1990 гг. западноевропейские страны приступили к модернизации модели всеобщего благосостояния с помощью глобальных реформ. В разных странах процесс шел с различной интенсивностью. Наиболее заметным он был, например, в Великобритании в период правления М. Тэтчер, где программы социальных реформ предполагали перемещение зависимого от государства трудоспособного населения на рынок труда, значительное сокращение социальных расходов, передачу значительной части государственной ответственности на региональный и коммунальный уровни, ужесточение условий доступа граждан к социальным услугам [Григорьева 2007] ${ }^{4}$.

Российские реформы совпали с той точкой мировых тенденций, когда в развитых странах происходило сворачивание социального государства. Поэтому понятие социального государства, легшее в основу Конституции 1993 г., сформулировано под влиянием именно этого контекста, а концепции самих реформ встроены в глобальный неолиберальный тренд. Отечественные реформаторы выбрали курс на либеральную модель под влиянием международных институтов вашингтонского

\footnotetext{
4 Сворачивание социального государства происходило по-разному: например, в Швеции роль государства все еще остается заметной. В странах Западной Европы до сих пор продолжаются споры о том, с чем именно был связан этот отход - с идеологическим неолиберальным проектом или с экономической необходимостью.
} 
консенсуса. Механизмы распространения неолиберальных взглядов в экспертной среде были убедительно показаны американскими исследователями Дж. Бокман и Г. Иель [Bockman, Eyal 2002]. Они, основываясь на теориях Б. Латура и М. Фуко, проанализировали установление господства неолиберальных взглядов в постсоциалистических странах, где в начальные годы реформ роль либеральных экономистов и международных консультантов была решающей ${ }^{5}$.

В России не ставились вопросы о том, что данная модель не вполне удовлетворяет своему основному назначению в условиях экономического спада, когда при вынужденном сокращении производства, сопровождаемом неизбежным урезанием социальных программ, в уязвимом положении оказались многие социальные группы. При этом другие модели были отвергнуты, например, социал-демократическая, основы которой уже были сформированы в советском опыте. Социальные расходы, как неэффективные и порождающие иждивенчество, рассматривались как бремя для экономики; социальное равенство ушло на задний план, а дифференциация стала важным критерием справедливости.

\section{Реформы 1990-х}

Если суммировать, кардинальные либеральные реформы социального обеспечения заключались во внедрении рыночных основ, децентрализации управления социальной сферой и индивидуализации рисков. В 1990-е гг. активно формировалось новое законодательство, регулировавшее развитие основных секторов социальной сферы (здравоохранения, образования, жилья), пенсионной системы и социальной помощи нуждающимся, и за основу был взят курс на либерализацию и резкое устранение государства от социального обеспечения.

Введение рыночных основ означало приватизацию учреждений, предоставлявших социальные услуги, и развитие рынка платных услуг. Причем реформирование в начале 1990-х гг. коснулось прежде всего систем здравоохранения, образования и жилья. В системе здравоохранения был усилен принцип социального страхования, произошли децентрализация и введение смешанных форм (частных и государственных) медицинских учреждений, легализован рынок платных медицинских услуг. Также был принят закон об обязательном медицинском страховании (1991 г.) с целью предоставления услуг в системе здравоохранения, основанном на принципе разделения затрат. Полностью на рыночные принципы перешел и жилищный сектор. Что касается системы образования, то она также претерпела существенные изменения: предусматривалось поступление финансирования образовательных учреждений от граждан в дополнение к бюджету, который был существенно сокращен, особенно это коснулось высшей школы.

Децентрализаиия системы управления сочиальной сферой. В советское время при строго централизованной вертикальной системе управления можно было напрямую регулировать процессы в любом регионе вплоть до административных

\footnotetext{
5 Примеры того, как это происходило в России, можно найти в воспоминаниях участников событий [Ананьин 2012; Григорьев 2012; Уринсон 2012; Глазьев 2012; Хаиткулов, Шестаков 2012], а также в других публикациях [Колодко 2011; Мюллер, Пикель 2002].
} 
районов. В 1990-е гг. становление трехуровневой власти (федеральный центр, региональная власть, местное самоуправление) определило принципиальный переворот в системе управления и в социальной политике. Причем юридически был закреплен принцип равенства различных организационно-правовых форм реализации социальной политики, а следовательно, партнерства множества ее субъектов. Идея заключалась в том, что социальная политика может реализовываться множеством взаимодействующих государственных и негосударственных акторов (организаций), а правовое регулирование постепенно должно приходить на смену административным методам управления. Поэтому весьма актуальной стала проблема обнаружения границ между акторами, секторами общества, пределов управленческих действий государства в отношении экономики и общества [Григорьева 2007].

Можно утверждать, что в начале реформ было проведено перераспределение фондов и ответственности, перевод непрофильных активов предприятий в распоряжение муниципалитетов. Следует напомнить, что особенностью советской социальной политики была ее прочная экономическая связь с так называемыми градообразующими предприятиями крупных индустриальных центров [Gough, McMylor 2000; Григорьев, Романов 2001]. На протяжении десятилетий функционирование и финансирование социальной сферы во многом определялись крупными промышленными предприятиями. Однако в 1990-е гг. многие государственные предприятия приватизировались, и со сменой форм собственности они стали избавляться от непрофильных активов. Была перераспределена ответственность между участниками социальных отношений: часть полномочий и объектов «соцкультбыта», принадлежавших предприятиям, передавалась органам местного самоуправления и муниципалитетам, при этом пользование ими планировалось в основном на платной основе. Изменились принципы финансирования социальной сферы и отдельных направлений социальной политики: значительные суммы из госбюджета были заменены обязательными страховыми взносами, для которых создавались внебюджетные социальные фонды.

Индивидуализаиия рисков. Принципиальным моментом, принятым во внимание реформаторами, была концепция перехода на индивидуализацию рисков. Подоплекой этого служило требование отхода от советской патерналистской системы и иждивенчества в сторону индивидуального ответственного выбора. Речь шла не просто о корректировке распределительных механизмов, а о создании условий свободного выбора индивидов, равных возможностей достижения благополучия [Концепция 1994].

Был изменен и правовой базис: если Конституции СССР были основаны на сильных коллективистских принципах, ставили во главу угла общественное благо, то Конституция, принятая в 1993 г., заостряла внимание на индивидуальных правах и свободах индивидов и их ответственности.

Введение платных услуг (например, медицинских), институтов страхования и адресной социальной помощи; изменение системы помощи и пособий семьям с несовершеннолетними детьми - все это, по мнению экспертов, должно было дисциплинировать население, воспитывать более ответственное отношение и к своему здоровью, и к использованию социальных услуг, стимулировать и мотивировать работников социальной сферы, в первую очередь здравоохранения, образования. Рыночный механизм рассматривался как самодостаточный, способный стать решением социальных проблем. 
Социальная политика этого периода получила название политики неотложHblx мер [Offe 1993], и многие преобразования в социальной сфере носили частичный, фрагментарный характер. Характерно, что дефиниции социальной политики обычно не претендуют на указание самостоятельной «субстанции», а даются через список сфер деятельности, например, помощь малообеспеченным, охрана здоровья, образование и т.п. Проводимые в 1990-е гг. меры часто называли «латанием дыр», заключающиеся в погашении задолженностей по выплате зарплаты бюджетникам, пенсий, детских пособий, а также в поддержание текущей работы учреждений здравоохранения, образования и культуры [Гонтмахер 2007]. Другие исследователи указывают, что в ситуации резкого падения уровня жизни населения, роста безработицы, преступности, бедности «правительство России было вынуждено идти на некоторое повышение зарплаты, пенсий и пособий, несмотря на требования Международного валютного фонда о снижении социальных расходов» [Ярская 2003, с. 48].

Проблемным местом виделось и то, как на практике определились зоны ответственности, ранжирование ролей и ресурсов в реализации социальной политики между центром, регионами и муниципалитетами. Напомним, что в начале 1990-х гг. социальные объекты перешли от предприятий к муниципалитетам. По мнению Е.Ш. Гонтмахера, «изменения, как планировалось, должны были дать позитивные изменения, однако ресурсная база местных властей и регионов была не в состоянии содержать и поддерживать объекты» [Гонтмахер 2007]. Финансирование социальной сферы местными органами власти составляло не более $10 \%$, из федерального центра шло не более $20 \%$, тогда как региональные власти играли самую существенную роль (70\%), что сильно осложняло межбюджетные отношения [Гонтмахер 2000, с. 16-18]. Своих средств на муниципальный социальный заказ у муниципалов не хватало, в такой ситуации предполагалось участие других акторов социальной политики - бизнеса и $\mathrm{HKO}^{6}$.

В 1990-е гг. надежды реформаторов проецировались на радикальные институциональные изменения по лекалам либерально-рыночной модели. Одновременно основной акцент преобразований был сделан на радикальные сокращения расходов на финансирование социальной сферы. Именно этот факт (вместе с приватизацией и либерализацией цен) часто упоминается в качестве концепции шоковой терапии. Однако результирующие тенденции оказались крайне противоречивыми: с одной стороны, появились новые рыночные институты и предпринимательство, с другой, стремительно падали показатели социального развития, резко выросло социальное неравенство.

Многие российские и зарубежные эксперты обращают внимание на политические интересы элит при проведении реформирования. М. Макфол полагает, что российская элита сознательно ограничила масштабы трансформации социальной политики для более оперативного осуществления шоковой терапии. $\mathrm{B}$ результате макроэкономические реформы были проведены за счет беднейших слоев населения, причем меры социальной защиты оказывались неэффективными [McFaul 1999]. Сравнительный анализ социальных трансфертов показывает, что в конце 1990-х гг. в России лишь 6\% социальной помощи достигали наименее

\footnotetext{
6 Тема частно-государственного партнерства стала обсуждаться более широко только в начале 2000-х гг. [Сидорина 2005].
} 
обеспеченные группы населения (для сравнения: в Польше - 29\%, Эстонии 36\%, США - 78\% [Manning, Shkaratan, Tikhonova 1997]). Помимо этого, в негативном свете утраты безопасности рассматриваются как ход реформ, так и процессы индивидуализации [Ferge 1997]. «Чтобы оптимально распределять дефицитные ресурсы, нужны поощрения и санкции, обращенные к интересам индивидов. Политическая теория такого рынка требовала жестких бюджетных сдержек. <..> Шоковая терапия стремилась девальвировать не только устаревшие физические мощности, но и старый “социальный” капитал» [Мюллер, Пикель 2002].

В конце 1990-х гг. многими экспертами были признаны просчеты в организации социальной политики, особенно болезненным оказалось ускоренное социальное расслоение. Рыночная трансформация практически во всех постсоциалистических странах сопровождалась скачкообразным ростом расслоения, однако признано, что именно в России проходили наиболее драматические преобразования по сравнению с другими посткоммунистическими странами. Важно напомнить, что в конце 1980-х гг. Россия наряду со скандинавскими странами входила в группу стран с низким уровнем дифференциации доходов. Период же масштабных социально-экономических и политических реформ 1990-х сопровождался существенным скачком доходного неравенства, и падение реальных доходов населения было более значительным, чем падение ВВП. Конец этого периода совпал с мировым финансовым кризисом; в 1998 г. был объявлен дефолт, когда реальная заработная плата (без учета скрытой части) упала до 27,2\% от уровня 1991 г., реальные доходы - до 42,6\%, а реальная пенсия - до 29,1\% [Овчарова, Пишняк, Попова, Шепелева 2013].

Согласно официальным данным Росстата, в первые годы структурных реформ в России (на фоне рецессии и двукратного падения доходов) фондовый коэффициент дифференциации увеличился с 4,5 раз в 1991 г. до 15,1 раза в 1994 г., коэффициент Джини вырос с 0,26 до 0,41 соответственно [Овчарова, Пииняк, Попова, Шепелева 2013]. Официальные показатели социального неравенства в дальнейшем варьировали уже вокруг значений 1994 г.

По мере реализации реформ усиливалось и разочарование населения: если в начале 1990-х примерно треть опрошенных была согласна с тем, что «большая разница в доходах необходима для процветания России», а 53\% не разделяли этих взглядов, то в 1999 г. доля сторонников глубоких различий в доходах сократилась до $13 \%$, а количество противников возросло до двух третей [Хахулина, Саар, Сmuвенсон 1996; Хахулина 2004]. В конце 1990-х гг. суть социальной политики, как ее видели россияне, часто сводилась к констатации, что «социальной политики нет» и «государство устранилось».

Высказывались мнения, что распространение рыночных отношений в российском обществе не только способствовало распространению индивидуалистического пессимизма, но и повысило ощущение неопределенности и дефицита государства, а следовательно, постепенно сформировало политическую потребность в более интенсивном вмешательстве государства [Хестанов 2003]. Исследователи отмечали, что «расставшись с иллюзиями начала 1990-х гг., массовое сознание пока не выработало новых представлений о социальной справедливости, свойственных нынешнемуэтапу развития экономики и общества». Ожидания того, что «невидимая рука» рыночных отношений сможет обеспечить справедливое распределение общественного богатства между социальными группами, хотя и имели определенное 
распространение, но не доминировали в общественном мнении. Так, в 2001 г. лишь треть опрошенных соглашалась с положением, что «в рыночной экономике главное - это дать людям возможность во всем проявлять свободную инициативу, а социальная справедливость установится сама собой», около $40 \%$ подобных взглядов не придерживались, и около $30 \%$ не имели на этот счет определенного мнения [Хахулина 2004 ].

2000-е годы - от «тучнылх» до кризисньых

Период 2000-2007 гг. часто называют «тучными годами». В это время наблюдалось улучшение макроэкономических показателей и внешней конъюнктуры; росли и доходы населения. По данным Росстата за 1999-2004 гг., реальные денежные доходы повысились на 68\%, начисленная заработная плата - на 107\%, размер назначенных пенсий - на 100\% при увеличении ВВП лишь на $39 \%$. В этот же период снижение реальной величины бюджетных расходов на образование и здравоохранение сменилось их увеличением на 76 и $56 \%$ соответственно. В целом за 1998-2007 гг. средние душевые реальные денежные доходы в ценах 1991 г. выросли в 3 раза, и это при условии, что ВВП увеличился в 1,8 раза [Овчарова, Пишняк, Попова, Шепелева 2013]. Экономический рост представлялся в значительной степени зависящим от высоких глобальных цен на энергоносители, которые повлияли на увеличение внутреннего потребления и объема инвестиций. В 2007 г. рост ВВП составил 8,1\%, экспорт нефти и газа - около $15 \%$ ВВП (60\% от общего объема экспорта). По мнению комментаторов, особенностью российской системы является зависимость от внешних факторов - цен на нефть. Более того, этому экзогенному фактору придается первостепенное значение: только в условиях устойчивого роста нефтяных отраслей функционирование всей экономической системы может обеспечить должным образом социальную интеграцию и солидарность [Cегаті 2009].

Также экспертами поднимается вопрос о так называемых хороших институтах. «Период 2000-х способствовал закреплению плохих институтов, сложившихся еще в 1990-е» [Кувшинова 2016]. Следует отметить, что подобная терминология связана с тем, что к концу 1990-х гг. в международном экспертном дискурсе на место концепции шоковой терапии пришла новая парадигма всеобъемлющего развития (comprehensive development framework). Трудности реформ в постсоциалистических странах породили некоторый пересмотр вашингтонского консенсуса. Требования «хорошего управления» и «реформ второго поколения» заменили жесткое противопоставление государства и рынка более конструктивным взглядом на роль политики государства в создании адекватной рынку институциональной среды, в том числе и социальной политики. Социальные, институциональные и организационные структуры посткоммунистических обществ полагались не внешними по отношению к процессам рынка, а эндогенными переменными, определяющими сами институты рынков и степень социального сплочения. Новая парадигма исходила из веры в демократию как лучший способ разрешения социальных конфликтов, стимулирования долгосрочного роста и создания справедливых хороших институтов [Мюллер, Пикель 2002]. 
В эти годы выросли расходы государства на социальную сферу: так, в 2000 г. российское правительство провозгласило курс на «субсидиарное социальное государство», что было некоторым отходом от ортодоксального либерализма [Григорьева 2008]. По сравнению с 1990-ми, когда жесткими и болезненными мерами была проведена реструктуризация во всех сферах социальной защиты, 2000-е гг. многие считают компенсаторным периодом, когда произошло переосмысление курса, взятого в 1990-е: вышло немало критических публикаций, анализирующих провалы радикальных либеральных реформ с точки зрения их соответствия «истинному либерализму» [Шляпентох 1998; Гринберг 2012]. Р. Гринберг связывает провалы экономических реформ и неприятие населением либеральных ценностей с игнорированием проблематики социальной справедливости [Гринберг 2012]. Статистика зафиксировала негативную динамику по показателям развития человеческого потенщиала, ухудшение состояния здоровья россиян, осложнение демографической ситуации, низкую продолжительность жизни. В то время повысился уровень смертности (с 1160 чел. на 100000 жителей в 1989 г. до 1510 чел. в 2005 г.), удвоилось злоупотребление алкоголем, увеличилось число больных СПИДом и ВИЧ-инфицированных в 131 раз по сравнению с показателями 1989 г. [Cerami 2009]. В 2000-е гг. уже отчетливо зазвучал призыв к сохранению человеческого капитала. Е.Ш. Гонтмахер констатирует, что 2000-е гг. характеризовались не просто усилением социальной политики, но и ее стремительным перемещением на первые места в приоритетах социально-экономического развития [Гонтмахер 2006]. Прежде всего это выражалось в запуске национальных приоритетных проектов «Здоровье», «Образование», «Доступное и комфортное жилье», стратегической демографической программы и других направлений, которые стали основными инструментами социальной политики и были направлены в первую очередь на комплексные задачи модернизации материально-технической базы социальной сферы, подготовку кадров и смену механизмов политики. Был введен ряд нормативных документов: новое трудовое законодательство, Жилищный кодекс, фактически запустивший механизм ипотеки; новации и эксперименты проводились в системе образования; проведено перераспределение бюджетных полномочий с федерального уровня на уровень субъектов РФ; обновилось иммиграционное законодательство. Вызвавшие немало споров нормативные документы последовательно ориентировались на основные принципы, заложенные еще с 1990-х гг., - рыночные основы, децентрализацию и индивидуализацию.

Побудительным мотивом усиления внимания к применению законов послужили и события вокруг монетизации льгот в 2004-2005 гг. Суть предложений заключалась в замене льгот, получаемых в натуральной форме (например, проезд на транспорте, лечение и т.п.), на денежные выплаты. Протесты продемонстрировали, что слишком резко проводимые реформы могут сформировать тормоз для их проведения. «События вокруг монетизации льгот сделали очевидными, с одной стороны, неотложность общественного запроса на сильную социальную политику, с другой - отсутствие тривиального ответа на этот запрос» [Якобсон 2010].

В то же время возникли разногласия относительно практических трудностей в ходе реализации проектов и среди экспертов, и внутри самого правительства: например, ошибки проявились в проекте «Доступное и комфортное жилье». Сразу же после официального объявления 5 сентября 2005 г. начался беспрецедентный 
рост цен на квартиры - и на новые, и на вторичном рынке. К концу 2006 г. цена квадратного метра, например, в Москве увеличилась в два раза, а в среднем по стране на 25-30\%. Нацпроект «Здоровье», призванный переломить негативные тенденции в сфере здравоохранения, сразу же вызвал недовольство в медицинском сообществе из-за неотлаженных механизмов оплаты труда медицинских работников. Также критиковалась реализация наиболее затратной части проекта, связанной с закупками медицинского оборудования, которые выполнялись по неэффективной схеме; помимо этого, в экспертном сообществе велись горячие споры вокруг ОМС и бюджетной медицины [Гонтмахер 2006].

Передача функций социального обеспечения в регионы совпала с налоговой и бюджетной реформами. Если до 2004 г. налоговое распределение между федеральным и региональными бюджетами осуществлялось в пропорции 50:50, то после принятия Федерального закона от 20 августа 2004 г. №120-Ф3 «О внесении изменений в Бюджетный кодекс Российской Федерации в части регулирования межбюджетных отношений» оно поэтапно изменилось до соотношения 70:30 в пользу федерального правительства. Очевидными были и противоречия в формулировке стратегий, и в слабости концептуальной базы и институтов. Уже в этот период многие исследователи отмечают гибридный характер российской модели. Е.Ш. Гонтмахер, например, писал о том, что федеральная политика, с одной стороны, использует перераспределительный патернализм национальных проектов, который в то же время сочетается с фискальными приоритетами в реформировании межбюджетных отношений и социальных расходов [Гонтмахер 2007]. При этом наблюдалось определенное согласие экспертов в том, что нацпроекты способствовали активизации социальной политики, но преобразования носили частичный фрагментарный характер [Гонтмахер 2007, Малева 2007, с. 425].

Начиная с 2008 г. экономика России стала замедлять свой рост, переходя в состояние стагнации на фоне мирового экономического кризиса и изменения внешней конъюнктуры. В кризисные годы в фокусе внимания социальной политики находились пенсионная система, здравоохранение, образование и демографическая ситуация: наблюдалось наращивание затрат на пенсионное обеспечение и социальную поддержку малообеспеченных групп населения; социальная политика концентрировалась на двух полюсах возрастного вектора - в отношении пожилого населения и семей с детьми.

Заметным было увеличения доли социиальных трансфертов в общем объеме доходов населения за счет роста пенсий и социальных пособий, что подверглось критике со стороны экспертов, которые указывали на опасность высокой доли социальных трансфертов, превышающей даже показатели, существовавшие в советские времена [Овчарова, Пишняк, Попова, Шепелева 2013]. Также в экспертной среде обсуждались уровень адресности региональных пособий и параметр необходимости при реализации мер социальной помощи. Ключевой темой для дискуссий становится «человеческий капитал», который теперь рассматривается экспертами как стратегическая ставка для экономического развития. Критике подвергаются приоритеты расходной части госбюджета, которые не соответствуют долгосрочным интересам развития человеческого потенциала.

Дискуссии о социальной справедливости все чаще стали привлекать публичное внимание, что явственно свидетельствовало о наличии общественного запроса на перемены. Социальная справедливость поместилась в цүентр официального 
дискурса и дискуссий о приоритетах социальной политики. Как ответ на общественный запрос в 2012 г. была опубликована предвыборная программная статья, название которой говорит само за себя: «Строительство справедливости. Социальная политика для России» [Путин 2012]. Казалось бы, в статье были отражены все основные чаяния общественности и сделаны ожидаемые акценты на многие вопросы современной социальной ситуации. Тем не менее обратим внимание на определенную иронию в том, как видится дилемма эффективности и справедливости, но при этом не ясны определения ни того, ни другого. «Эффективность социальной политики измеряется мнением людей - справедливо ли устроено общество, в котором мы живем» [Путин 2012]. Под, казалось бы, ожидаемыми формулировками скрывается фикция: эффективность не измеряется фактическим улучшением положения людей, главное - что думают люди, в подстрочнике просвечивается мотив легитимации проводимой политики и сохранения лояльности населения. В популистском ключе звучит и заключение «каждый рубль, направляемый в социальную сферу, должен “производить справедливость”» [Путин 2012]. Однако неясно, как конкретно это должно происходить.

Как бы парадоксально это ни звучало, но в программной статье отчетливо декларируется курс следованию неолиберальной логике социальной политики, но при возрастании роли государства в распределении ресурсов. Прослеживается сочетание акцентов на развитие внебюджетного финансирования, негосударственной и корпоративной сферы платных социальных услуг, индивидуализации рисков при одновременном упоре на распределительные механизмы, связанные с повышением зарплат работников бюджетной сферы - здравоохранения, образования, науки - на основе оценки эффективности их труда. При этом ответственность государства четко закреплена в области борьбы с бедностью и поддержания социально-уязвимых групп через систему пособий и выплат (перечисленные области, как известно, включены в целевые показатели социальной политики). Снижение же социального неравенства не является целевым показателем постсоветской социальной политики. Неравенство признается правомерным и саморегулируемым: «Определенная степень дифференциации доходов естественна для зрелой рыночной экономики, однако избыточный разрыв воспринимается как несправедливость и служит источником социальной напряженности» [Путин 2012]. Исправить эту ситуацию, видимо, под силу самим гражданам. «Поэтому важнейшая задача уменьшение материального неравенства. Как за счет более адресной и эффективной социальной политики, так - $и$ в первую очередь - за счет возможности каждому зарабатывать, обеспечить себе достаточный уровень доходов» [Путин 2012].

При этом исследования констатируют наличие глубокого структурного и воспроизводящегося социального неравенства с начала 1990-х. Все эти годы показатели неравенства менялись мало, с некоторыми смещениями колебались коэффициент Джини $(0,40-0,42)$ и коэффициент фондов (14-16 раз) [Григорьев 2017 ]. Обеспокоенность высоким социальным неравенством последнее время официально выражается в том, что оно в годы неблагоприятного экономического развития является источником политической и экономической нестабильности [Медведев 2016].

Весьма значительно региональное (территориальное) неравенство, которое эксперты называют застойнылм, существенны различия между уровнем жизни в развитых и неразвитых регионах, между городами и сельскими местностями, меж- 
ду крупными и малыми городами [Зубаревич 2013]. Неравенство воспроизводится в разных уровнях доходов занятых в различных секторах экономики, прежде всего монополизированных (топливно-энергетические отрасли), приносящих ренту, и немонополизированных, конкурентных (переработка, пищевая промышленность, сельское хозяйство).

Траектория воспроизводящихся неравенств совершенно очевидна во всех социологических исследованиях [Горшков 2010; Мареева 2013; Черныш 2015; Шкаратан, Ястребов 2016]. Разрыв между бедными и богатыми остается высоким, даже сокращение бедных категорий граждан не поспевает за увеличением доходов наиболее богатых; улучшения «жизненных шансов» и возможностей заработать не наблюдается и в тенденциях мобильности; также не растут пропорции и позиции среднего класса. Одновременно с этим трудно обойти вниманием факт увеличения числа миллиардеров, обладающих огромными состояниями, источники которых не вписываются в какой-либо известный канон социальной справедливости. Многие социологи отмечают, что сложившаяся на данный момент ситуация в России не отвечает представлениям населения о справедливости, даже показывают, что большинство россиян уверены в несправедливости устройства нашего общества [О справедливости и несправедливости 2017]. Несправедливость ассоциируется не только с социальным расслоением, но и с нарушением принципа равной ответственности перед законом, несовершенством и зависимостью судебной системы. Несправедливыми людям видятся сами условия жизни - размер зарплат и пособий, доступность тех или иных социально-экономических благ, качественной медицины и образования, жилья и многое другое. Вопреки растиражированному мнению о широком распространении среди населения эгалитарных и патерналистских представлений исследования такого факта не фиксируют. Опросы общественного мнения свидетельствовали, что имеет место очевидный плюрализм в понимании справедливости: по данным опроса ВЦИОМ, «63\% россиян хотели бы жить в обществе социального равенства, но почти столько же $(60 \%)$ полагают, что оно, в принципе, недостижимо». Среди возможных вариантов социальной справедливости наиболее популярной была признана меритократическая модель (39\%), предполагающая, что достаток определяется «количеством и качеством труда и заслугами конкретного человека»; на второе место вышло «государство равных возможностей» (32\%); уравнительную систему, при которой материальные и духовные блага распределяются для всех поровну вне зависимости от их вклада в общее дело, предпочли 19\% респондентов; а за модель общественного устройства, при котором каждый заботится о себе сам, а государственная помощь оказывается только незащищенным слоям населения, высказались всего 5\% [Федоров 2010]. В работах российских социологов отмечается, что недовольство граждан связано с тем, что на практике серьезно нарушаются общие принципы справедливости, которые отвечают не столько эгалитарным, сколько либерально-меритократическим, в духе Дж. Ролза, ценностям [Черныш 2015]. Отечественные исследователи анализируют многомерный характер справедливости (дистрибутивный и процедурный): одни видят влияние институциональных сил в микроконтексте, когда граждане сталкиваются с несправедливостью в своей повседневной жизни [Римский 2013; Черныш 2015], другие пишут в более широком контексте, считая, что россияне не видят работающих каналов социальной мобильности [Мареева 2013]. 
С 2012 г., когда вышли майские указы президента, и по сей день их директивный характер и исполняемость помещаются во главу угла внутриполитической борьбы и подвергаются острой критике со всех сторон. Официально трудности в реализации указов связывают с условиями ухудшающейся внешней конъюнктуры, со снижением цен на нефть, внешними санкциями и застойным развитием экономики. Но если не принимать во внимание внешние неблагоприятные условия, исполнение майских указов обнажает узловые противоречия и проблемы во всей системе социальной политики. Главное, на что направлена критика, нереалистичность выполнения указов в существующих структурных условиях, прежде всего из-за недостатков бюджетной политики - возложения расходов и ответственности на региональные уровни власти при смещении самих доходов в федеральный центр. Опасение вызывает тот факт, что при директивном управлении и нехватке средств реализация указов превратится в фикцию, что, собственно, и происходит в системе оплаты труда работников бюджетной сферы. Хорошо известны схемы перевода одних категорий работников в другие, увеличения зарплат на бумаге путем формальных перерасчетов, на деле же работники получают те же или даже меньшие зарплаты. Для оценки эффективности используются различные целевые показатели, однако в основном они не отражают качество и уровень жизни людей, а лишь говорят об исполнении плановых показателей финансирования.

Противоречия видны и в так называемой борьбе с бедностью. По признанию экспертов, программа удвоения ВВП в сочетании с сокращением масштабов бедности была задумана как отчетливо либеральная: устанавливалось ограничение на процент граждан за пределами порога бедности, а в остальном приоритетное значение придавалось темпам экономического роста, которого в реальности не происходило. В этих условиях ориентация на либеральный принцип «помоги себе сам, а самым бедным поможет государство» имела оборотную сторону, когда в борьбе с бедностью важная роль отводилась государственным социальным трансфертам. Возникла опасность возрастания социального иждивенчества: люди стремятся получать разного рода выплаты, а не работать, что вряд ли повысит эффективность и снизит нагрузку на бюджет. Кроме того, до сих пор имеются методические трудности определения крайней бедности, нуждаемости, адресности социальной помощи. В России официальное определение бедности базируется на абсолютной концепции ее измерения, а основным индикатором является доля населения с доходами ниже прожиточного минимума, что постоянно требует пересмотра, не говоря уже о том, что минимальная зарплата и социальная пенсия - ниже прожиточного минимума.

Противоречия выражаются и в нарушении баланса между зонами ответственности и зонами ресурсов, когда сам принцип децентрализации предполагает лазейку для невыполнения социальных обязательств. Например, исполнение отдельных мер социальной поддержки формально гарантировано федеральным законодательством, однако на деле их реализация отнесена к компетенции регионов или муниципалитетов, не обладающих достаточным финансированием, которое проводится только по мере выделения ассигнований из федерального бюджета. Это значит, что отсутствие финансирования дает законное основание для отказа гражданину в предоставлении закрепленных федеральным законом прав: нет денег - нет ни мер, ни услуг. 


\section{Заключение}

Российская социальная политика, находясь под воздействием экзогенных и эндогенных факторов и являясь результатом внутриполитической борьбы, претерпевала трансформации на протяжении всего советского и постсоветского времени.

Суть заключается в том, что российский режим социальной политики или социального государства, впрочем, как и капитализма, не вписывается ни в одну из представленных моделей и имеет кентаврический (гибридный) характер. С одной стороны, изменения системы социального благосостояния осуществлялись в соответствии с неолиберальной логикой реформ [Матвеев 2016]. Реформирование, например, таких отраслей, как образование, здравоохранение и культура, подчинено принципу рыночной эффективности, который на практике сводится к гонке за долей платных услуг в учреждениях. Регулярно проводятся попытки «оптимизации» и перевода на принцип самоокупаемости и сокращения всей сети бюджетных учреждений. Государство тем самым перекладывает социальные расходы на плечи граждан. Противоречие видится в том, что в отсутствии экономического роста ограничены возможности граждан в получении достойных доходов и соответственно снижена доступность услуг, прежде всего качественных. С другой стороны, меняется само государственное управление, все больше переходящее в авторитарный способ перераспределения ресурсов. Противоречие наблюдается в воплощении принципа децентрализации управления - сочетание регионализации обязательств по социальной политике при остром дефиците региональных бюджетов и усиления контроля над ресурсами из центра. Это сочетается со специфическим набором техник государственного распределения и регулирования, поддерживающих не столько население, сколько бюрократическую машину. Роль государства воплощается не в субсидиарности, а в субординировании (подчинение центру). Патернализм в отношении к регионам сочетается с патримониальным характером властных отношений с регионами и внутри них [Гельман 2015]. Такой тип приближен к модели, которую можно охарактеризовать как рудиментарную, свойственную некоторым странам Латинской Америки; от социал-демократической модели (во многом близкой советской) не осталось и следа.

«Кентавризм» проявляется в официальной и публичной риторике. Лавирование между иллюзиями эффективности и справедливости остается основным приемом власть предержащих вне зависимости от политической принадлежности. Первая иллюзия происходит из твердого убеждения части правящей элиты в успешности неолиберальной модели и способности рынка решить все социальные и экономические проблемы. Притом что большинство правящей элиты, в том числе и либеральной, живет за счет перераспределения государственного бюджета и поддержки государственных компаний, догма «эффективности рынка» не подвергается никакому сомнению и составляет основу целеполагающей риторики о реформах в социальной сфере. Другая иллюзия опирается на веру населения в великое соииальное государство, которое заботится об общем благе. Социальная составляющая постоянно преподносится в официальной риторике как главная в политике государства на основании того, что государство по Конституции остается социальным, и что в последние годы выражается в «мантре» об исполнении президентских указов. Однако на деле социальное обеспечение имитируется, 
предоставляя раздаточным способом «остатки» населению в качестве небольших увеличений пенсий, пособий и зарплат бюджетников. При росте расходов на модернизацию социальной сферы львиная доля идет на поддержание монополизированных зон и в коррупционный оборот. Все эти годы социальная политика не приводит к снижению неравенства, которое закрепилось на уровне высоких показателей начала 1990-х гг. и представляет структурную черту общества. При этом выигравшим остается административный класс, концентрирующий в своих руках власть и собственность, а простые россияне, постепенно избавляясь от иллюзий, вынуждены выживать. Насколько осуществимо поддерживать иллюзию справедливости, покажет время, но представляется важным озаботиться внятностью социальной политики и вниманием к проблемам социального неравенства, которые оставались в тени проводимой политики.

\section{Литература}

Авен П. (1987) Механизм распределения и социальная справедливость // Коммунист. № 15 . С. $115-122$.

Ананьин О.И. (2012) Как сложились команда реформаторов и ее программа, или о неофициальном экономическом дискурсе в реформаторском движении 1980-х годов // Мир России. № 1. С. 3-10.

Гельман В. (2015) Модернизация, институты и «порочный круг» постсоветского неопатримониализма. СПб.: Европейский Университет.

Глазьев С.Ю. (2012) Либеральные реформы в России: правда и вымысел // Мир России. № 1. C. $37-51$.

Гонтмахер Е.Ш. (2000) Принципы и основные элементы социальной стратегии // Территориальные проблемы социальной политики. М.: ВШЭ. С. 16-18.

Гонтмахер Е.Ш. (2006) Приоритетные национальные проекты (попытка политэкономического осмысления) // Журнальный зал // http://magazines.russ.ru/nz/2006/50/go19.html

Гонтмахер Е.Ш. (2007) Социальная политика: тенденции последних 15 лет и возможные перспективы // ИНО-Центр // http://www.ino-center.ru/news/doc/203 gontmaher.pdf

Горшков М. К. (2010) Социальные неравенства как вызов современной России // Вестник Института социологии. № 1. С. 24-47.

Григорьев Л.М. (2012) Хронология реформ. Экономические реформы конца ХХ в.: опыт и уроки новейшей истории // Мир России. № 1. С. 11-23.

Григорьев Л. (2017) Доходы населения в период выхода экономики из рецессии // Бюллетень о текущих тенденциях российской экономики. № 22 // http://ac.gov.ru/files/publication/a/11944.pdf

Григорьев О.А., Романов П.В. (2001) Муниципализация социальной инфраструктуры предприятий. Саратов: Абрис.

Григорьева И.А. (2007) Российская социальная политика в последние годы: между уже пройденным путем и все еще неопределенным будущим // Журнал исследований социальной политики. № 1. С. 7-24.

Григорьева И. (2008) Социальная политика в России: поиски вариантов и направлений трансформации // Романов П.В., Ярская-Смирнова Е.Р. (ред.) Социальная политика в современной России: реформы и повседневность. М.: Вариант, ЦСПГИ. С. 19-42.

Гринберг Р.С. (2012) Свобода и справедливость. Российские соблазны ложного выбора. М.: Магистр Инфра-М.

Гусев И.Т., Калашников Н.П., Качанов А.В., Колобашкин В.М. и др. (1982) Профессиональная ориентация молодежи и организация приема в высшие учебные заведения. М.: Высшая школа. 
Епихина Ю.Б. (ред.) (2016) Социальная справедливость в русской общественной мысли. М: Институт социологии РАН.

Заславская Т.И. (1986) Человеческий фактор развития экономики и социальная справедливость // Коммунист. № 13. С. 61-73.

Зубаревич Н. (2013) Неравенство доходов населения: пространственная проекция // Pro et Contra. № 6. C. 48-60.

Колодко Гж. (2011) Новый прагматизм против рушащегося неолиберализма // НИУ ВШЭ // https://iq.hse.ru/news/177672562.html

Концепция социальной политики в России (из доклада Института социально-экономических проблем народонаселения РАН) (1994) // Общественные науки и современность. № 6. C. 23-31.

Кувшинова О. (2016) ВШЭ: Трансформация экономики России продлится 10 лет // Ведомости // https://www.vedomosti.ru/economics/articles/2016/04/20/638490-vshetransformatsiya-ekonomiki

Кузнецов Н.С. (1984) Справедливость как ценность и роль ценностных отношений развитого социализма // Общественные отношения развитого социализма. Свердловск: УрГУ. С. 145-154.

Лойко Л.И. (1985) Социальная справедливость в условиях социалистического общества (методологический аспект) // Вестник Харьковского университета. № 281. С. 96-103.

Малева Т.М. (ред.) (2007) Обзор социальной политики в России. Начало 2000х годов. М.: НИСП.

Мальцев Г. (1985) Социальная справедливость и правовые основы распределения по труду // Общественные науки. № 1. С. 27-41.

Мареева С.В. (2013) Справедливое общество в представлениях россиян // Общественные науки и современность. № 5. С. 16-26.

Матвеев И. (2016) Неолиберализм с российскими характеристиками // openDemocracy.net // https://www.opendemocracy.net/od-russia/ilya-matveev/rossiya-inc

Медведев Д. (2016) Социально-экономическое развитие России: обретение новой динамики. // Вопросы экономики № 10. С. 5-30.

Мюллер К., Пикель А. (2002) Смена парадигм посткоммунистической трансформации // Социологические исследования. № 9. С. 67-82.

Наумова Н.Ф., Роговин В.З. (1987) Задача на справедливость // Социологические исследования. № 3. С. 12-23.

О справедливости и несправедливости в российском обществе (2017) // Фонд «Общественное мнение» // http://fom.ru/TSennosti/13279

Овчарова Л., Пишняк А., Попова Д., Шепелева Е. (2013) От стандарта выживания к ответственному выбору // Pro et Contra. № 6. С. 6-34.

Осипенко О. (1986) Нетрудовые доходы и формы их проявления // Экономические науки. № 11. C. $63-70$.

Путин В.В. (2012) Строительство справедливости. Социальная политика для России // Комсомольская правда // https:/www.kp.ru/daily/25833/2807793/

Римский В.Л. (2013) Справедливость в современной России: мечты и использование в социальных практиках // Общественные науки и современность. № 5. С. 27-36.

Роговин В. (1985) Наследство // Комсомольская правда. 7 июня 1985. № 129 (18333). С. 2.

Романов П.В. (2003) Социальная политика и социальные изменения // Журнал исследований социальной политики. № 1. С. 45-66.

Сигов И.И., Слуцкий Е.Г. (2006) Социальное государство: сущность, критерии и приоритеты развития. М.: Ин-т проблем региональной экономики.

Сидорина Т.Ю. (1998) Социальная политика и ее акторы // Мир России. № 1-2. С. 147-192.

Сидорина Т.Ю. (2005) Два века социальной политики. М.: РГГУ.

Сравнительный анализ структурных сдвигов в посткоммунистическом мире: социальная справедливость, равенство шансов, социальная солидарность (материалы круглого стола) (2011) // Мир России. № 4. С. 3-23.

Уринсон Я.М. (2012) Экономические реформы: взгляд из Министерства экономики // Мир России. № 1. С. 24-36.

Федоров В.В. (2010) Новая социальная структура и политические ценности россиян // Мониторинг общественного мнения. № 4. С. 264-275. 
Хаиткулов Р.Г., Шестаков Д.Е. (2012) Российские экономические реформы: история эволюции концепций // Мир России. № 1. С. 54-78.

Хахулина Л.А., Саар А., Стивенсон С.А. (1996) Представление о социальной справедливости в России и Эстонии: сравнительный анализ // Мониторинг общественного мнения. № 6. С. 19-25.

Хахулина Л.А. (2004) Динамика оценок населением России справедливости и несправедливости неравенств, сложившихся в 90-е годы // НИУ ВШЭ // http://www.hse.ru/data/650/313/1234/2004_01_20.pdf

Хестанов Р. (2003) Эссе о времени, труде и капитале // Отечественные записки. № 3 // http://www.strana-oz.ru/2003/3/esse-o-vremeni-trude-i-kapitale

Церкасевич Л.В. (2002) Современные тенденции социальной политики в странах Европейского союза. СПб.: СПбГУЭФ.

Черныш М.Ф. (2015) Социальные институты, мобильность и социальная справедливость: опыт одного исследования // Мир России. № 4. С. 7-28.

Шкаратан О.И., Ястребов Г.А. (ред.) (2016) Нова ли Новая Россия. М.: Университетская книга.

Шляпентох В.Э. (1998) Равенство и справедливость в России и США // Социологический журнал. № 3/4. С. 250-258.

Шохин А. (1987) Борьба с нетрудовыми доходами: социально-экономический аспект // Плановое хозяйство. № 2. С. 83-89.

Якобсон Л.И. (2010) Перспективы социальной политики. Социальная политика: коридоры возможностей // Экономика. Социология. Менеджмент // http://ecsocman.hse.ru/data/2010/12/09/1214860940/Yakobson.pdf

Ярская В.Н. (2003) Социальная политика, социальное государство и социальный менеджмент: проблемы анализа // Журнал исследований социальной политики. № 1 . C. $45-67$.

Bockman J., Eyal G. (2002) Eastern Europe as a Laboratory for Economic Knowledge: The Transnational Roots of Neoliberalism // American Journal of Sociology, vol. 108, no 2, pp. 310-352.

Cerami A. (2009) Welfare State Developments in the Russian Federation: Oil-Led Social Policy and the 'Russian Miracle'// Social Policy \& Administration, vol. 43, no 2, pp. 105-120.

Esping-Andersen G. (1990) Three Worlds of Welfare Capitalism, Princeton.

Ferge Zs. (1997) The Changed Welfare Paradigm - The Individualization of The Social // Social Policy and Administration, vol. 31, no 1, pp. 20-44.

George V., Manning N. (1980) Socialism, Social Welfare and the Soviet Union, London, Boston and Henley: Routledge.

Gough I., McMylor P. (2000) Enterprise Welfare and Economic Transition in Russia // Global Capital, Human Needs and Social Policies (ed. Gough I.), Houndmills; New York: Palgrave, pp. 153-176.

Manning N., Shkaratan O., Tikhonova N. (2000) Work and Welfare in the New Russia, Aldershot: Ashgate.

McFaul M. (1999) The Political Economy of Social Policy Reforms in Russia: Ideas, Institutions and Interests // Left Parties and Social Policy in Postcommunist Europe (eds. Cook L.J., Orenstein M.A., Rueschemeyer M.), Oxford: Westview Press, pp. 207-234. 


\title{
Transformations in the Welfare Regime and Discourse on Social Justice in Russia
}

\author{
E. DANILOVA*
}

\begin{abstract}
*Elena Danilova - PhD in Sociology, Head, Center for Theoretical and Historical Sociological Research, Institute of Sociology RAS, Federal Research Sociological Center RAS. Address: bldg 5, Krzhizhanovskogo 24/35, Moscow, 117218, Russian Federation. E-mail: endanilova@gmail.com
\end{abstract}

Citation: Danilova E. (2018) Transformations in the Welfare Regime and Discourse on Social Justice in Russia. Mir Rossii, vol. 27, no 2, pp. 36-61 (in Russian). DOI: 10.17323/1811-038X-2018-27-2-36-61

\begin{abstract}
This article investigates the main tendencies in the welfare provision in the Russian Federation in correspondence to the discourse of social justice during the Soviet era and after the fall of communism. The paper argues that the debates around social justice in the official rhetoric and expert opinions occur explicitly when there is a public need for the justification and legitimation of social changes. The paper also identifies periods in the development of social policy due to the variety of different, but equally important, endogenous and exogenous factors such as the presence of national economic vulnerabilities, the presence of contradictory measures, and non-contingent decisions taken by the government. The article shows that social policy in Russia, being under the influence of exogenous and endogenous factors and being the result of internal political struggles at each stage, has been transformed into a model that does not fit any of the proposed theoretical regimes of welfare state. It has a centauric nature, in which the neoliberal logic of reform is combined with an authoritarian state management and a heavy bureaucratic regulatory machine. Social policy, even in the years of its recovery, did not reduce social inequality, which remains high ever since its rapid rise in the early 1990s.
\end{abstract}

Key words: social justice, discourse, social policy, reform, social state, social inequality

\section{References}

Anan'in O.I. (2012) Kak slozhilis' komanda reformatorov i ee programma, ili o neofitsial'nom ekonomicheskom diskurse v reformatorskom dvizhenii 1980-kh godov [The Origins of the Russian Reformers and their Programme. Some Facts about Informal Economic Discourse in the 1980s]. Mir Rossii, no 1, pp. 3-10.

Aven P. (1987) Mekhanizm raspredeleniya i sotsial'naya spravedlivost' [The Mechanism of Distribution and Social Justice]. Kommunist, no 15, pp. 115-122. 
Bockman J., Eyal G. (2002) Eastern Europe as a Laboratory for Economic Knowledge: The Transnational Roots of Neoliberalism. American Journal of Sociology, vol. 108, no 2, pp. 310-352.

Cerami A. (2009) Welfare State Developments in the Russian Federation: Oil-Led Social Policy and the 'Russian Miracle'. Social Policy \& Administration, vol. 43, no 2, pp. 105-120.

Chernysh M.F. (2015) Sotsial'nye instituty, mobil'nost' i sotsial'naya spravedlivost': opyt odnogo issledovaniya [Social Institutions, Mobility and Social Justice: the Results of a Study]. Mir Rossii, no 4, pp. 7-28.

EpikhinaYu.B (ed.) (2016) Sotsial'naya spravedlivost'v russkoj obshchestvennoj mysli [Social Justice in the Russian Social Thought], Moscow: IS RAS.

Esping-Andersen G. (1990) Three Worlds of Welfare Capitalism, Princeton.

Fedorov V.V. (2010) Novaya sotsial'naya struktura i politicheskie tsennosti rossiyan [The New Social Structure and the Political Values of Russians]. Monitoring obshchestvennogo mneniya, no 4, pp. 264-275.

Ferge Zs. (1997) The Changed Welfare Paradigm - The Individualization of The Social. Social Policy and Administration, vol. 31, no 1, pp. 20-44.

Gel'man V.(2015) Modernizatsiya, intituty $i$ «porochnyj krug»postsovetskogoneopatrimonialisma [Modernazation, Institutions, and the "Vicious Circle" of post-Soviet Neo-patrimonialism], Saint Petersburg: Evropeiskii Universitet.

George V., Manning N. (1980) Socialism, Social Welfare and the Soviet Union, London, Boston and Henley: Routledge.

Glaz'ev S.Yu. (2012) Liberal'nye reformy v Rossii: pravda i vymysel [Liberal Reform in Russia: The Truths and Myths]. Mir Rossii, no 1, pp. 37-51.

Gontmaher E.Sh. (2000) Printsipy i osnovnye elementy sotsial'noj strategii [Principles and Main Elements of Social Strategy]. Territorial'nye problemy sotsial'noj politiki [Territorial Problems of Social Policy], Moscow: HSE, pp. 16-18.

Gontmaher E.Sh. (2006) Prioritetnye natsional'nye proekty (popytka politekonomicheskogo osmysleniya) [Prioritized National Projects (an Attempt at Political Economic Understanding)]. Zhurnal'nyj zal. Available at: http://magazines.russ.ru/nz/2006/50/go19, accessed 28 February 2018.

Gontmaher E.Sh. (2007) Sotsial'naya politika: tendentsii poslednikh 15 let i vozmozhnye perspektivy [Social Policy: Trends During Recent 15 Years and Possible Perspectives]. INO-Center. Available at: http://www.ino-center.ru/news/doc/203_gontmaher.pdf, accessed 28 February 2018.

Gorshkov M. K. (2010) Sotsial'nye neravenstva kak vyzov sovremennoj Rossii [Social Inequality as a Challenge for Contemporary Russia]. Vestnik Instituta sotsiologii, no 1, pp. 24-47.

Gough I., McMylor P. (2000) Enterprise Welfare and Economic Transition in Russia. Global Capital, Human Needs and Social Policies (ed. Gough I.), Houndmills; New York: Palgrave, pp. $153-176$.

Grigor'ev L.M. (2012) Khronologiya reform. Ekonomicheskie reformy kontsa XX v.: opyt i uroki noveishei istorii [A Chronology of Reform. Economic Reform of the Late XXth Century: Lessons and Experience from the Recent History]. Mir Rossii, no 1, pp. 11-23.

Grigor'ev L. (2017) Dokhody naseleniya v period vykhoda [Incomes of the Population in the Period of Economic Recovery from Recession]. Bulleten' o tekuschikh tendentsiyakh rossikoj ekonomiki, no 22. Available at: http://ac.gov.ru/files/publication/a/11944.pdf, accessed 28 February 2018.

Grigor'ev O.A., Romanov P.V. (2001) Munitsipalizatsiya sotsial'noj infrastruktury predpriyatij [Municipalization of Enterprises' Social Infrastructure], Saratov: Abris.

Grigor'eva I.A. (2007) Rossijskaya sotsial'naya politika v poslednie gody: mezhdu uzhe projdennym putem i vse eshche neopredelennym budushchim [Russia's Social Policy in the Recent Years: Between the Past and the Unknown Future]. Zhurnal issledovanij sotsial'noj politiki, no 1, pp. 7-24.

Grigor'eva I. (2008) Sotsial'naya politika v Rossii: poiski variantov i napravlenij transformatsii [Social Policy in Russia: a Search for Alternatives and the Directions of Transformation]. Sotsial'naya politika v sovremennoj Rossii: reformy i povsednevnost' [Social Policy in Modern Russia: Reforms and Everyday Life] (eds. Romanov P., Yarskaya-Smirnova E.), Moscow: Variant, CSPGI, pp. 19-42. 
Grinberg R.S. (2012) Svoboda i spravedlivost'. Rossijskie soblazny lozhnogo vybora [Freedom and Justice. Temptations of a False Choice], Moscow: Magistr Infra-M.

Gusev I.T., Kalashnikov N.P., Kachanov A.V., Kolobashkin V.M. (1982) Professional'naya orientatsiya molodezhi i organizatsiya priema $v$ vysshie uchebnye zavedeniya [Professional Orientation of Youth and the Organization of Admission to Higher Educational Institutions], Moscow: Vysshaya shkola.

Khaitkulov R.G., Shestakov D.E. (2012) Rossijskie ekonomicheskie reformy: istoriya evolyutsii kontseptsii [Russian Economic Reform: a History of the Concept's Evolution]. Mir Rossii, no 1 , pp. 54-78.

Khakhulina L.A. (2004) Dinamika otsenok naseleniem Rossii spravedlivosti i nespravedlivosti neravenstv, slozhivshikhsya v 90-e gody [Changes in the Public Evaluation of Justice and Injustice of the Inequality that Established in the 1990s]. NRU HSE. Available at: http://www.hse.ru/data/650/313/1234/2004 01 20.pdf, accessed 28 February 2018.

Khakhulina L.A., Saar A., Stephenson S.A. (19996) Predstavlenie o sotsial'noj spravedlivosti v Rossii i Estonii: sravnitel'nyj analiz [The Notion of Social Justice in Russia and Estonia: a Comparative Analysis]. Monitoring obshchestvennogo mneniya, no 6, pp. 19-25.

Khestanov R. (2003) Esse o vremeni, trude I kapitale [An Essay on Time, Labor and Capital]. Otechestvennye zapiski, no 3. Available at: http://www.strana-oz.ru/2003/3/esse-o-vremenitrude-i-kapitale, accessed 28 February 2018.

Kolodko G. (2011) Novyi pragmatizm protiv rushashchegosya neoliberalizma [New Pragmatism Against Crumbling Neoliberalism]. NRU HSE. Available at: https://iq.hse.ru/news/177672562.html, accessed 28 February 2018.

Kontseptsiya sotsial'noj politiki v Rossii (iz doklada Instituta sotsial'no-ekonomicheskikh problem narodonaseleniya RAN) (1994) [The Concept of Social Policy in Russia (From the Report of the Institute of Social and Economic Problems of Population of the Russian Academy of Sciences)]. Obshchestvennye nauki i sovremennost', no 6, pp. 23-31.

Kuvshinova O. (2016) VSHE: Transformatsii ekonomiki Rossii prodlitsya 10 let [HSE: Economic Transformations in Russia Will Last 10 Years]. Vedomosti. Available at: https://www.vedomosti.ru/economics/articles/2016/04/20/638490-vshe-transformatsiyaekonomiki, accessed 28 February 2018.

Kuznetsov N.S. (1984) Spravedlivost' kak tsennost' i rol' tsennostnykh otnoshenij razvitogo sotzsializma [Justice as the Value and Role of the Value Relations in the Developed Socialism]. Obshchestvennye otnosheniya razvitogo sotsializma [The Social Relations in the Developed Socialism], Sverdlovsk: UrGU, pp. 145-154.

Lojko L.I. (1985) Sotsial'naya spravedlivost' v usloviyah sotsialisticheskogo obshchestva (metodologicheskij aspekt) [Social Justice in a Socialist Society (a methodological aspect)]. Vestnik Khar 'kovskogo universiteta, no 281, pp. 96-103.

Maleva T.M. (ed.) (2007) Obzor sotsial'noj politiki v Rossii. Nachalo 2000-kh [The Survey on Social Policy in Russia. The Beginning of 2000s], Moscow: NISP

Mal'tsev G. (1985) Sotsial'naya spravedlivost' i pravovye osnovy raspredeleniya po trudu [Social Justice and the Legal Basis for Distribution According to Labor]. Obshchestvennye nauki, no 1 , pp. 27-41.

Manning N., Shkaratan O., Tikhonova N. (2000) Work and Welfare in the New Russia, Aldershot: Ashgate.

Mareeva S.V. (2013) Spravelivoe obschestvo v predstavleniyakh rossiyan [A Just Society in the Views of Russians]. Obschestvennye nauki i sovremennost', no 5, pp. 16-26.

Matveev I. (2016) Neoliberalism s rossiiskimi chertami [Neoliberalism with Russian Traits]. openDemocracy.net. Available at: https://www.opendemocracy.net/od-russia/ilya-matveev/ rossiya-inc, accessed 28 February 2018.

McFaul M. (1999) The Political Economy of Social Policy Reforms in Russia: Ideas, Institutions and Interests. Left Parties and Social Policy in Postcommunist Europe (eds. Cook L.J., Orenstein M.A., Rueschemeyer M.), Oxford: Westview Press, pp. 207-234.

Medvedev D. (2016) Sotsial'no-ekonomicheskoe razvitie Rossii: obretenie novoj dinamiki [Socialeconomic Development of Russia: Finding New Dynamics]. Voprosy ekonomiki, no 10, pp. 5-30.

Muller K., Pickel A. (2002) Smena paradigm postkommunisticheskoj transformatsii [Change in the Paradigms of Post-communist Transformation]. Sotsiologicheskie issledovaniya, no 9, pp. 67-82. 
Naumova N.F., Rogovin V.Z. (1987) Zadacha na spravedlivost' [The Task of Justice]. Sotsiologicheskie issledovaniya, no 3, pp. 12-23.

O spravedlivosti i nespravedlivosti v rossijskom obshchestve (2017) [On Justice and Injustice in the Russian Society]. Fond "Obeshchestvennoe mnenie». Available at: http://fom.ru/TSennosti/13279, accessed 28 February 2018.

Osipenko O. (1986) Netrudovye dokhody i formy ikh proyavleniya [The Unearned Income and the Forms of Its the Survival Standard to the Responsible Choice]. Pro et Contra, no 6, pp. 6-34.

Putin V.V. (2012) Stroitel'stvo spravedlivosti. Sotsial'naya politika dlya Rossii [Building Justice. Social Policy for Russia]. Komsomol'skaya pravda. Available at: https://www.kp.ru/daily/25833/2807793/, accessed 28 February 2018.

Rimskij V.L. (2013) Spravedlivost'v sovremennoj Rossii: mechty i ispolzovanie v sotsial'nykh practikakh [Justice in Contemporary Russia: the Dreams and the Practical Use]. Obshchestvennye nauki i sovremennost', no 5, pp. 27-36.

Rogovin V. (1985) Nasledstvo [Inheritance]. Komsomol'skaya pravda, June 7 1985, no 129 (18333), p. 2.

Romanov P.V. (2003) Sotsial'naya politika i sotsial'nye izmeneniya [Social Policy and Social Changes]. Zhurnal issledovanij sotsial'noj politiki, no 1, pp. 45-66.

Shkaratan O.I., Yastrebov G.A. (eds.) (2016) Nova li novaya Rossiya? [Is New Russia New?], Moscow: Universitetskaya kniga.

Shlyapentokh V. E. (1998) Ravenstvo i spravedlivost' v Rossii i SShA [Social Equality and Justice in Russia and USA]. Sotsiologicheskij zhurnal, no 3/4, pp. 250-258.

Shokhin A. (1987) Bor'ba s netrudovymi dokhodami: sotsial'no-ekonomicheskij aspekt [Combating Unearned Income: the Socio-economic Aspect]. Planovoe khozyajstvo, no 2, pp. 83-89.

Sidorina T.Yu. (1998) Sotsial'naya politika i ee aktory [Social Policy and Its Actors]. Mir Rossii, no $1-2$, pp. 147-192.

Sidorina T.Yu. (2005) Dva veka sotsial'noj politiki [Two Centuries of Social Policy], Moscow: RGGU.

Sigov I.I., Sluckij E.G. (2006) Sotsial'noe gosudarstvo: sushchnost', kriterii i prioritety razvitiya [Welfare State: Essence, Criteria and Development Priorities], Moscow: In-t problem regional'noj ekonomiki.

Sravnitel'nyj analiz strukturnykh sdvigov $\mathrm{v}$ postkommunisticheskom mire: sotsial'naya spravedlivost', ravenstvo shansov, sotsial'naya solidarnost' (materialy kruglogo stola) (2011) [Comparative Analysis of Structural Shifts in the Post-communist World: Social Justice, Equality of Chances, Social Solidarity (Round Table Materials)]. Mir Rossii, no 4, pp. 3-23.

Tserkasevich L.V. (2002) Sovremennye tendentsii sotsial'noj politiki v stranakh Evropeiskogo Sojuza [Recent Trends in Social Policy in the Countries of European Union], Saint Petersburg: SPbGUEF.

Urinson Ya.M. (2012) Ekonomicheskie reformy: vzglyad iz Ministerstva ekonomiki [Economic Reform: a View from the Ministry for National Economy]. Mir Rossii, no 1, pp. 24-36.

Yakobson L.I. (2010) Perspektivy sotsial'noj politiki. Sotsial'naya politika: koridory vozmozhnostej [Prospects of Social Policy. Social Policy: Corridors of Opportunities]. Economics. Sociology. Management. Available at: http://ecsocman.hse.ru/data/2010/ 12/09/1214860940/Yakobson.pdf, accessed 28 February 2018.

Yarskaya V.N. (2003) Sotsial'naya politika, sotsial'noe gosudarstvo i sotsial'nyj menedzhment: problemy analiza [Social Policy, Welfare State and Social Management: Problems of Analysis]. Zhurnal issledovanij sotsial'noj politiki, no 1, pp. 45-67.

Zaslavskaya T.I. (1986) Chelovecheskij faktor razvitiya ekonomiki i sotsial'naya spravedlivost' [The Human Factor of Economic Development and Social Justice]. Kommunist, no 13, pp. 61-73.

Zubarevich N. (2013) Neravenstvo dokhodov naseleniya: prostranstvennaya proektsiya [Income Inequality: a Spatial Projection]. Pro et Contra, no 6, pp. 48-60. 